\title{
Pola Aktivitas HarianPasangan Burung Serak Jawa (Tyto alba) di Sarang Kampus Psikologi Universitas Diponegoro Tembalang Semarang
}

\author{
Mochamad Hadi \\ Laboratorium Ekologi dan Biosistematik Jurusan Biologi FMIPA Undip
}

\begin{abstract}
Abstrak
Burung serak jawa (Tyto alba) merupakan hewan nocturnal. Burung T. alba biasanya bersarang pada bangunan tua dan gedung yang tinggi dengan menempati sarang yang sudah ada atau mengambil alih sarang yang ditinggalkan burung lain. Kemampuan bersarang pada gedung dan bangunan ini menyebabkan $T$. alba mampu menempati gedung di kampus Psikologi Universitas Diponegoro Tembalang Semarang. Sifat $T$. alba untuk menempati gedung kampus Psikologi Universitas Diponegoro dapat mempermudah perkembengbiakan, namun potensi untuk perjumpaan dengan manusia juga sangat besar. Penelitian ini bertujuan untuk mengetahui pola distribusi waktu yang digunakan oleh Tyto alba untuk aktivitas hariannya. Teknik pengamatan scaning sampling digunakan sebagai dasar penentuan alokasi waktu untuk aktivitas burung hantu T. alba seperti, terbang, bertengger, berburu, istirahat, bercumbu dan bertarung. Pengamatan dilaksanakan selama 14 X 24 jam, dengan 12 jam hari terang dan 12 jam hari gelap. Penentuan pola aktivitas harian dengan menghitung rata - rata total aktivitas $T$. alba selama 24 jam. Aktivitas harian yang paling banyak dilakukan oleh pasangan T. alba adalah aktivitas istirahat (14 jam 44 menit) dengan puncak waktu istirahat pada siang hari. Waktu yang dihabiskan untuk istirahat $T$. alba betina lebih tinggi (15 jam 53 menit). Alokasi waktu yang digunakan untuk bertengger T. alba betina (2 jam 56 menit) sebagai bentuk proteksi terhadap sarang. T. alba jantan bertanggung jawab memberikan kebutuhan nutrisi pada $T$. alba betina waktu yang digunakan untuk berburu (7 jam 40 menit). Pasangan T. alba melakukan aktivitas bertarung secara bersamaan (5 menit) dan waktu untuk bercumbu (4 menit).
\end{abstract}

Kata kunci : serak jawa, Tyto alba, nocturnal, aktivitas harian

\section{PENDAHULUAN}

$$
\text { Burung merupakan suatu obyek }
$$

pelestarian keanekaragaman hayati karena manfaatnya terhadap kelangsungan dan kesejahteraan hidup manusia. Manfaat secara langsung adalah sebagai komoditi ekonomi, sedang manfaat burung secara tidak langsung, yaitu untuk menjaga kestabilan ekosistem (Prasetyo, 2002).

Pemanfaatan burung dalam menjaga kestabilan ekosistem diantaranya burung Serak Jawa (Tyto alba). Burung T. alba termasuk burung buas (carnivora) yang aktif pada malam hari atau nocturnal (Anonim, 2002). Pada siang hari T. alba menggunakan waktunya untuk beristirahat di dalam sarang (Mackinon, 2000).

Menurut Baskoro (2005), T. alba tidak membuat sarang seperti burung berkicau, biasanya menggunakan sarang yang sudah ada atau mengambil alih sarang yang ditinggalkan. Burung T. alba juga bersarang pada bangunan, gedung yang tinggi, serta lubang pohon. Burung T. alba merupakan burung pemangsa yang tentunya memiliki peran penting bagi lingkungan (Bachynski dan Harris, 2002). Perannya sebagai pemangsa puncak (Top Predator) menjadikanya sebagai salah satu komponen keseimbangan dalam rantai makanan. Hilangnya salah satu komponen dalam rantai makanan ini dapat mengganggu kestabilan ekosistem secara keseluruhan. Mengingat peran penting burung T. alba dalam keseimbangan ekosistem, maka upaya perlindungan terhadapnya perlu ditingkatkan. Upaya untuk dapat menjalankan perlindungan diperlukan informasi cukup mengenai satwa burung $T$. alba. berdasarkan informasi ini, dilakukan pengkajian pola aktivitas harian $T$. alba selama 24 jam, guna 
mengetahui waktu yang digunakan oleh $T$. alba untuk aktivitas hariannya.

Burung serak jawa (T. alba) pertama kali di deskripsikan oleh Giovani Scopoli tahun 1769. Nama alba berkaitan dengan warnanya yang putih (Lewis, 1998). Burung T. alba termasuk dalam famili Tytonidae yang memiliki 25 genus yang terdiskripsi dan untuk species Tyto yang sudah terdeskripsikan terdapat 17 jenis (Lewis,1998). Menurut Setiawan (2004), T. alba mempunyai ciri-ciri kepala besar dan membulat, wajah berbentuk hati berwarna putih dengan tepi kecoklatan, mata menghadap ke depan sehingga mudah dikenali, iris mata berwarna hitam. Paruh tajam menghadap kebawah, warna keputihan. Sayap dan punggung terdapat tanda mengkilap. Sayapnya didominasi warna kelabu, sawo matang dan berwarna putih Kaki panjang dan kelihatan sangat kokoh serta mempunyai daya cengkeram yang kuat. Mangsanya dicengkeram dengan jarijari yang bercakar tajam. Bulu pada kaki sangat jarang.

Karena aktif pada malam hari $T$. alba mempunyai sistem pendengaran yang sangat baik. Telinga terletak pada samping kepala, dibawah mata dan tertutup oleh bulu-bulu muka. Mata $T$. alba yang besar berguna untuk meningkatkan efisiensi, khususnya pada kondisi pencahayaan yang rendah. Matanya berkembang sangat baik untuk melihat pada malam hari. (Baskoro, 2005).

Menurut Lewis (1998), burung jantan dan betina hampir sama dalam ukuran dan warna meski betina sedikit lebih besar. Betina mempunyai panjang tubuh $34-40 \mathrm{~cm}$, mempunyai bentangan sayap $\pm 110 \mathrm{~cm}$ dan mempunyai berat badan $570 \mathrm{~g}$, yang jantan ukuran panjang 32-38 $\mathrm{cm}$, dengan bentangan sayap \pm 107 dan berat badan 470 g. $T$. alba jantan biasanya warnanya coklat atau agak kekuningan, sedang yang betina berwarna coklat ke abu-abuan. Bulu dada betina berwarna putih kecokelatan, sedangkan jantan berwarna sedikit keputihan dengan jumlah bintik hitam yang lebih sedikit dibandingkan dengan burung betina dan burung $T$. alba muda yang mempunyai bercak lebih rapat (Barn Owl Trust, 2001).

Permasalahan yang muncul adalah bagaimana pola distribusi waktu yang digunakan oleh burung serak jawa ( $T$. alba) selama 24 jam untuk aktivitas hariannya di kampus Psikologi Universitas Diponegoro dimana terdapat penerangan pada malam hari dan adanya kontak dengan manusia.
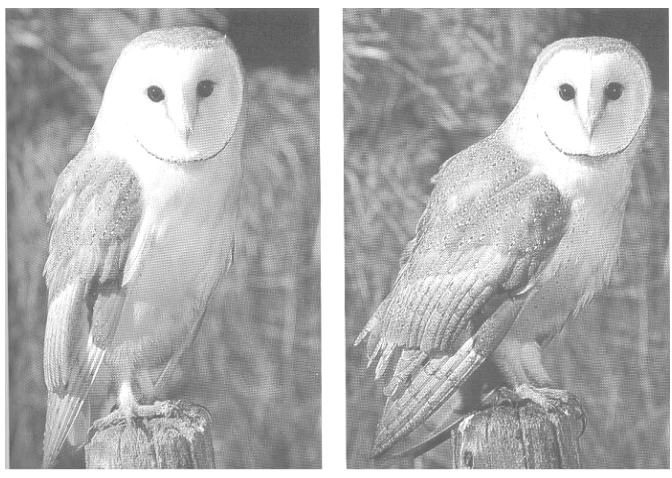

Gambar 1. Burung Tyto alba. (a) jantan dan (b) betina (Read and Alsop, 1994).

\section{Pola perilaku Tyto alba}

Kebanyakaan burung hantu aktif pada malam hari terutama saat senja dan subuh. Pada siang hari waktu dihabiskan unutuk istirahat atau bertengger dengan tenang. Umumnya mereka bertengger sendiri dan kadang berpasangan.

Aktivitas harian burung hantu dimulai dengan membersihkan, menjilati, menguap dan menggaruk kepala dengan cakar. Bulu-bulu seringkali disisir dan sayap dibersihkan dengan kaki dan paruh. T. alba ketika meninggalkan tempat bertengger kadang dengan bersuara (Baskoro, 2005).

\section{A. Perilaku Istirahat}

Menurut Mackinon (2000) sepanjang hari T. alba bersembunyi pada lubang yang gelap di rumah atau gedung, lubang pohon dan vegetasi yang rapat termasuk hutan mangrove. T. alba merupakan hewan nocturnal, sehingga pada waktu siang hari dihabiskan untuk istirahat (The Hawk \& Owl Trust, 2004).

\section{B. Perilaku Bertengger}

Semua burung hampir rutin membersihkan bulunya dari debu, kotoran, dan parasit. Burung $T$. alba melakukannya dengan menggunakan paruh dan cakarnya. Pada bulu terbang terdapat kait-kait yang saling mengunci membuat bulu menjadi satu permukaan. Kait ini sering kali terlepas pada waktu terbang. Burung menggunakan paruhnya 
untuk menyusun ulang kait yang terlepas dan mengembalikan bulu pada kondisi yang terbaik. Ada kelenjar yang disebut uropygial, terletak didekat ekor yang menghasilkan cairan berminyak. Kelenjar ini dirangsang oleh paruh, yang digunakan untuk menstransfer cairan kebulu -bulu untuk dijadikan lapisan pelindung (Baskoro, 2005).

\section{Perilaku Berburu}

T. alba mempunyai indera penglihatan yang sangat tajam. Sistem binokuler-nya yang sangat baik menyebabkan burung hantu dapat memantau mangsanya tanpa menggerakkan kepala. T. alba dapat mendeteksi gerakan sedikit saja dari mangsanya. Kemampuan berburu sangat tinggi, tangkas dan handal dan memiliki daya dengar dan penglihatan yang sangat tajam. Bulunya yang halus tidak menimbulkan suara di saat terbang memburu mangsanya (Setiawan, 2004).

Menurut Lewis (1998), burung hantu $T$. alba adalah pemangsa pada malam hari yang menyukai binatang kecil seperti tikus-tikus, kelinci, kekelawar, burung, kodok, kadal dan serangga. T. alba mulai berburu setelah matahari terbenam, berburu berikutnya sekitar 2 jam menjelang fajar. Namun jika sedang mengasuh anak mereka akan berburu sepanjang malam (Baskoro, 2005).

Burung hantu T. alba tidak pernah memangsa cecurut berit (Suncus murinus) karena mengeluarkan bau busuk dan burung $T$. alba tidak suka makan bangkai tikus. Dari analisis terhadap kotorannya, diketahui bahwa 99\% terdiri atas tikus, sedangkan sisanya adalah serangga. Burung hantu dewasa setiap hari sanggup memakan sekitar 2-3 ekor tikus hidup, tergantung pada besar kecilnya tikus. Bila ukuran tikus relatif kecil, maka langsung ditelannya secara utuh, bila tikus yang ditangkapnya cukup besar, maka akan dipotongpotongnya menjadi beberapa bagian sebelum ditelan (Setiawan, 2004)

Tujuan penelitian untuk mengetahui pola aktivitas harian $T$. alba dan distribusi waktu yang khas yang digunakan oleh $T$. alba untuk aktivitas harian.

Diharapkan dari penelitian ini diperoleh informasi mengenai perilaku dan pola distribusi waktu yang digunakan oleh $T$. alba untuk aktivitas harianya. Sehingga upaya untuk perlindungan, pelestarian dan pemanfaatannya dapat dilakukan secara optimal.

\section{HASIL DAN PEMBAHASAN}

Hasil pengamatan perilaku T. alba dapat dilihat pada Tabel 1 dan Gambar 4.1 yang menunjukan aktivitas burung hantu T. alba seharihari dengan proporsi yang berbeda -beda.

Tabel 1. Perbadingan Aktivitas T. alba jantan dan betina serta rata-rata aktivitas pasangan.

\section{Perilaku ( jam)}

\begin{tabular}{lcccccc}
$\begin{array}{l}\text { Indivi } \\
\text { du }\end{array}$ & $\begin{array}{c}\text { Istira } \\
\text { hat }\end{array}$ & $\begin{array}{c}\text { Bteng } \\
\text { ger }\end{array}$ & $\begin{array}{c}\text { Ter } \\
\text { bang }\end{array}$ & $\begin{array}{c}\text { Ber } \\
\text { buru }\end{array}$ & $\begin{array}{c}\text { Bcu } \\
\text { mbu }\end{array}$ & $\begin{array}{c}\text { Ber } \\
\text { tarung }\end{array}$ \\
\hline Jantan & $13.34^{\prime}$ & $1.30^{\prime}$ & $1.07^{\prime}$ & $7.40^{\prime}$ & $0.04^{\prime}$ & $0.05^{\prime}$ \\
Betina & $15.53^{\prime}$ & $2.56^{\prime}$ & $0.58^{\prime}$ & $4.07^{\prime}$ & $0.04^{\prime}$ & $0.05^{\prime}$ \\
$\begin{array}{c}\text { Rata- } \\
\text { rata }\end{array}$ & $\mathbf{1 4 . 4 4}$ & $\mathbf{2 . 1 3}$ & $\mathbf{1 . 0 3}$ & $\mathbf{5 . 5 4}$ & $\mathbf{0 . 0 4}$ & $\mathbf{0 . 0 5}$ \\
\hline
\end{tabular}

Rata - rata Total Aktivitas Harian Tyto alba selama 24 jam

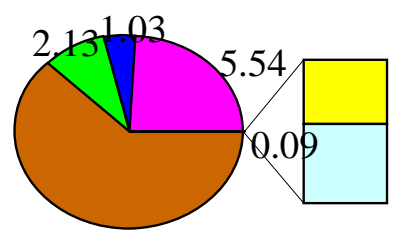
$\begin{array}{ll}0.04 & \begin{array}{l}\text { aIstirahat } \\ \text { aBertengger } \\ \text { aTerbang } \\ \text { aBerburu } \\ \text { aBercumbu } \\ \text { aertarung }\end{array} \\ 0.05\end{array}$ 14.44

Gambar 2 Diagram Rata -rata aktivitas harian $T$. Alba selama 24 jam

Pengamatan yang dilakukan selama 24 jam menunjukan rataan kegiatan harian burung hantu di kampus UNDIP adalah (14 jam 44 menit) istirahat, (5 jam 54 menit) berburu, (2 jam 13 menit) digunakan untuk bertengger, (1 jam 3 menit) untuk terbang, (5 menit) bertarung dan (4 menit) digunakan untuk bercumbu.

Rataan kegiatan istirahat dan bertengger lebih tinggi pada $T$. alba betina sedang rataan kegiatan terbang, berburu lebih tinggi pada $T$. alba 
jantan. Perbandingan aktivitas T. alba jantan dan betina dapat dilihat pada diagram 4.2.

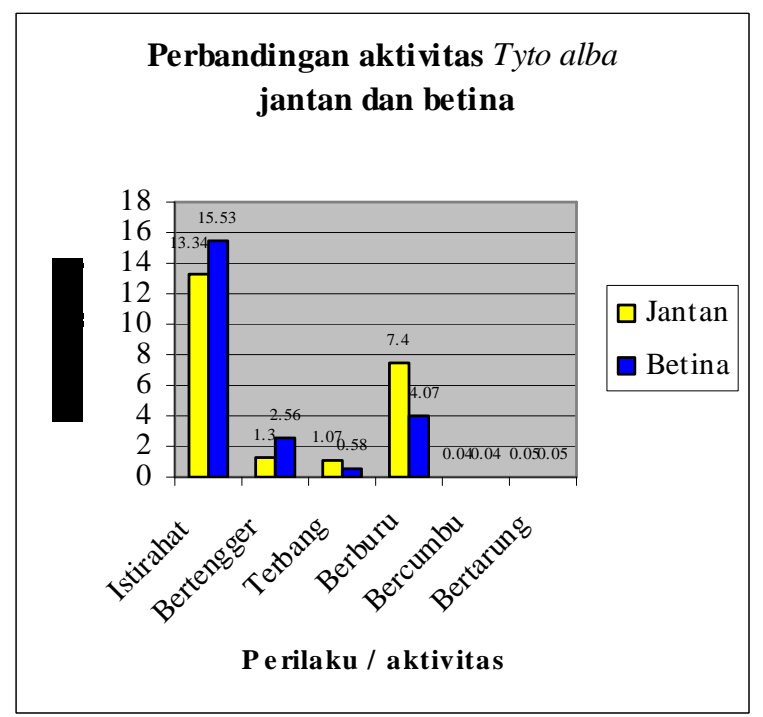

Gambar 3. Diagram Perbandingan Aktivitas $T$. alba Jantan dan Betina

\section{Perilaku Istirahat}

Aktivitas istirahat burung hantu mayoritas dilakukan pada siang hari sedang pada malam hari T. alba menghabiskan waktunya untuk beraktivitas. Menurut Mackinon (2000) burung hantu T. alba termasuk burung nocturnal, karena burung $T$. alba aktiv beraktivitas pada malam hari.

Hasil pengamatan total waktu perilaku istirahat $T$. alba selama 24 jam untuk burung $T$. alba betina lebih tinggi sekitar 15 jam 53 menit sedang pada $T$. alba jantan 13 jam 34 menit yaitu 12 jam pada siang hari yang digunakan untuk tidur, sedang malam hari untuk $T$. alba betina istirahat di dalam sarang atau bertengger di dalam sarang sekitar 4 jam sedang jantan sekitar 1 jam 30 menit.

T. alba pada siang hari tidak melakukan aktivitas atau dihabiskan untuk istirahat. Waktu $T$. alba keluar dari sarang sekitar jam 18.00 dan masuk kesarang pukul 05.00, pada jam 18.00 matahari sudah terbenam serta pada pukul 05.00 cahaya matahari belum terang sehingga pengelihatanya tidak terganggu. Cahaya matahari yang terang membuat sistem pengelihatannya kurang jelas. Menurut Baskoro (2005) mata $T$. alba tidak berupa bola mata namun serupa tabung. Retina T. alba memiliki banyak "rod sel" yang sensitif terhadap cahaya. T. alba yang aktif pada siang hari dimungkikan $T$. alba kelaparan atau tidak dapat mangsa pada malam hari.

\section{Perilaku Bertengger}

Ativitas bertengger pada burung T. alba dilakukan sering disekitar sarang ditujukan pada gambar 4.3. Waktu bertengger yang dibutuhkan betina lebih tinggi dari yang jantan. Waktu untuk bertengger $T$. alba betina 2 jam 56 menit sedang untuk jantan sekitar 1 jam 30 menit. Waktu betina lebih tinggi aktivitas betina cenderung untuk proteksi terhadap sarang dari T. alba lain. Sesuai (Martin, 2005) T. alba bertengger sebagai bentuk mempertahankan dan proteksi dari $T$. alba lain yang masuk ke sarang dan daerah teritorialnya. Bertengger pada T. alba sering dilakukan dengan menggangkat salah satu kakinya ditunjukan pada gambar 4.3.

Burung T. alba betina bertanggung jawab dalam proteksi terhadap sarang sehingga waktu bertengger lebih tinggi sedang T. alba jantan lebih aktif berburu untuk memberi makan pada $T$. alba betina sehingga tetap survive.

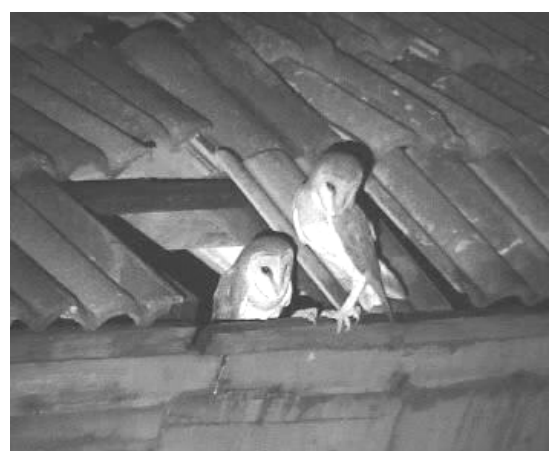

Gambar 4. Burung serak jawa (Tyto alba) bertengger di mulut sarang (sebelah kiri betina dan sebelah kanan jantan). 


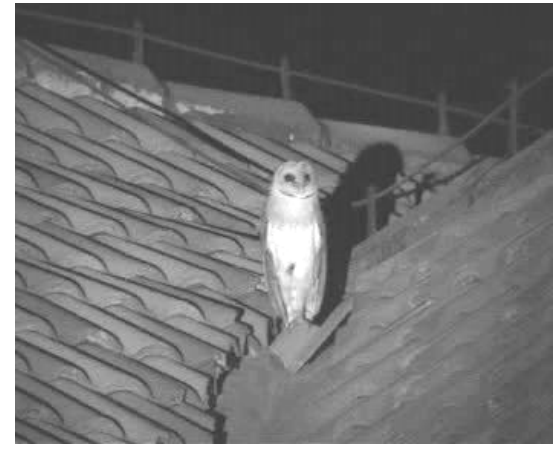

Gambar 5. Tyto alba betina bertengger diatap kampus psikologi dengan mengangkat salah satu kakinya.

\section{Perilaku Terbang}

Dari hasil pengamatan aktivitas terbang dilihat dari gambar 6 waktu terbang jantan lebih tinggi dari yang betina. Waktu yang dibutuhkan $T$. alba jantan untuk terbang 1 jam 07 menit sedang untuk betina 58 menit. Pada waktu terbang burung hantu sangat jarang mengepakan sayap. Menurut Mackinon (2000) terbang yang tidak mengepakan sayap biasanya disebut gliding. T. alba jantan pada saat terbang seringkali berteriak sedang $T$. alba betina jarang atau hampir tidak pernah teriak ketika terbang.

Waktu terbang yang dibutuhkan T. alba jantan lebih tinggi dari pada T. alba betina. T. alba jantan lebih aktif berburu dari pada T. alba betina yang cenderung untuk proteksi terhadap sarang dari Tyto alba lain sehingga T. alba betina kurang aktif atau lebih banyak bertengger disekitar sarang. Aktivitas terbang burung T. alba dapat dilihat pada gambar 6

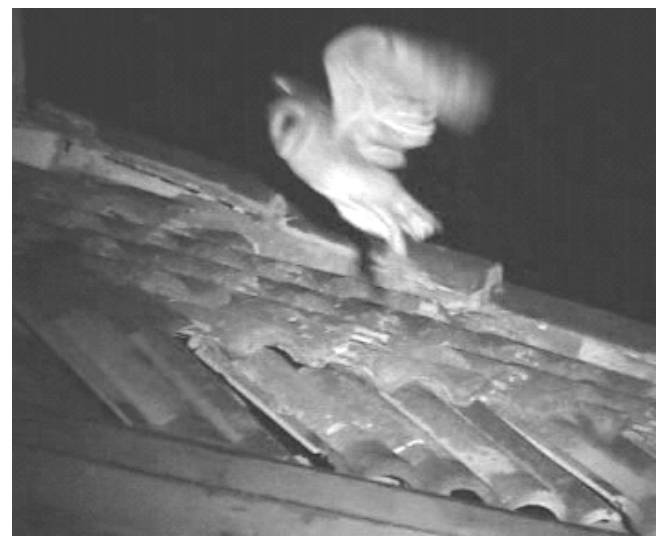

Gambar 6. Tyto alba yang sedang terbang

\section{Perilaku Berburu}

Aktivitas berburu T. alba dimulai sejak senja sampai 2 jam sebelum matahari terbit. Aktivitas berburu dan memangsa $T$. alba jantan lebih tinggi dari betina. Total waktu yang digunakan oleh $T$. alba untuk berburu selama 24 jam, untuk T. alba jantan 7 jam 40 menit sedang yang betina 4 jam 07 menit.

T. alba jantan sering kali membawa hasil buruan untuk betina sehingga aktivitas berburu jantan lebih tinggi dari yang betina. T. alba jantan bertanggung jawab untuk memberikan asupan nutrisi pada $T$. alba betina. Sebelum T. alba jantan memberikan hasil buruan kepada $T$. alba betina, diawali terlebih dahulu T. alba jantan bertengger pada atap sekitar sarang untuk memindah mangsa yang dibawa dengan cakarnya dari tempat buruan ke paruh baru diberikan pada betina. Aktivitas $T$. alba jantan sebelum memberikan mangsa kepada T. alba betina dapat dilihat pada gambar 4.6 dan 4.7.

Jumlah mangsa yang diberikan $T$. alba jantan kepada $T$. alba betina sekitar 3 mangsa dalam waktu satu malam. Hal ini sesuai dengan (Setiawan, 2004) T. alba dewasa sanggup memakan mangsa sekitar 2-3 terutama tikus hidup dalam waktu semalam. Hasil buruan T. alba jantan yang sering diberikan kepada $T$. alba betina biasanya berupa tikus dan kekelawar. Mangsa $T$. alba mayoritas adalah hewan kecil, tikus, kelinci, katak, burung kecil, serangga dan termasuk juga kelelawar. T. alba juga termasuk hewan oportunis, hewan yang dapat memangsa apapun yang ada didaerahnya (Lewis, 1998).

T. alba langsung menelan mangsa yang kecil seperti kelelawar dan tikus, sedang untuk mangsa yang besar $T$. alba mencabik atau memotong-motong mangsa menjadi bagian yang lebih kecil dengan paruhnya terlebih dahulu agar mudah dalam proses penelanan. Hal ini sesuai dengan Setiawan (2004) T. alba langsung menelan secara utuh tikus yang ukuran kecil,sedang tikus ukuran besar akan dipotong-potong menjadi beberapa bagian sebelum ditelan. Awalnya, burung ini akan memotong leher tikus menggunakan paruhnya. Sasaran utama yang menjadi santapan adalah kepala tikus yang akan ditelan bersama-sama kulit serta bulunya. Bagian tubuh mangsa yang tidak bisa dicerna (tulang dan 
rambut) dipadatkan menjadi pelet yang akan dimuntahkan (regurgitasi) sekitar 6 jam setelah dicerna (del Hoyo, 1999).

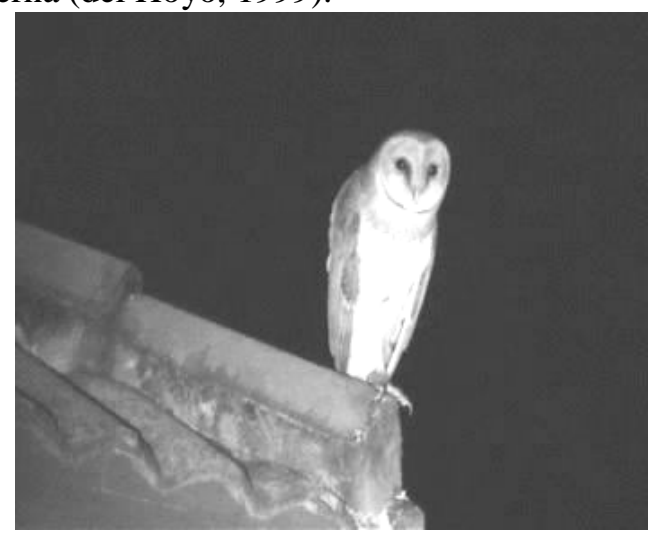

Gambar 7. Tyto alba jantan bertengger dengan membawa mangsa dikaki.

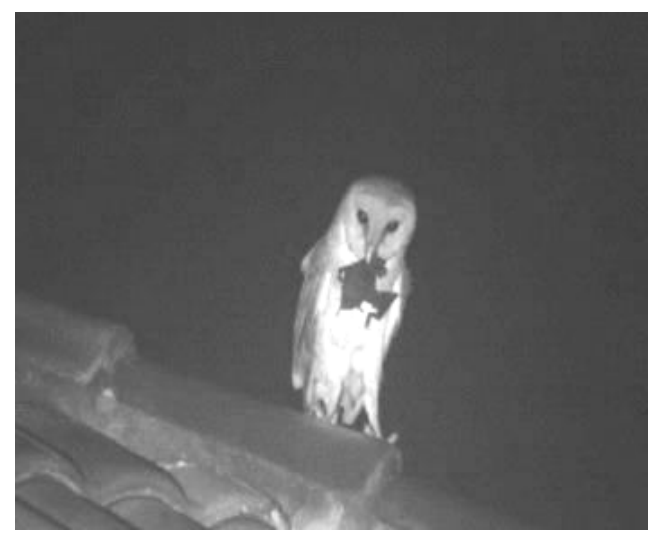

Gambar 8 Tyto alba jantan memindah mangsa (kelelawar) dimulut

\section{Perilaku Bercumbu}

Perilaku bercumbu pada burung T. alba biasanya dilakukan pada saat pasangan burung $T$. alba bertengger. Total waktu yang digunakan $T$. alba untuk bercumbu selama 24 jam yaitu 4 menit.

Pola aktivitas bercumbu burung ini mulamula burung $T$. alba jantan mendekati burung $T$. alba betina, sambil meyengolkan badan ke tubuh T. alba betina. T. alba betina merendahkan badannya setelah itu burung jantan naik kepunggung $T$. alba betina dan melakukan kopulasi. Kopulasi pada burung hantu T. alba ini sering dilakukan sekitar 2-4 kali dalam semalam. Waktu yang digunakan untuk kopulasi sangat cepat sekitar 7 detik. Menurut del Hoyo (1999) periode berbiak burung T. alba pada bulan maret sampai bulan agustus bila terjadi ledakan hama tikus dapat menyebabkan populasi burung $T$. alba meningkat.

\section{Perilaku Bertarung}

Aktivitas bertarung T. alba terjadi ketika burung hantu lain masuk daerah teritorinya atau pada saat burung hantu $T$. alba lain mendekati sarang. Pengusiran dan bertarung sebagai bentuk T. alba untuk mempertahankan atau proteksi daerah teritori dan sarang yang ditempatinya. Waktu yang dibutuhkan terjadinya perilaku bertarung $T$. alba sebagai bentuk proteksi sekitar 5 menit. Pada saat bertarung T. alba jantan lebih agresif untuk mengusir $T$. alba lain yang datang disarang.

Pengusiran T. alba jantan dengan mengejar T. alba lain yang masuk kedaerah teritorinya sehingga terjadi pertarungan yang dilakukan dengan terbang dan saling mencakar, untuk betina berada di sekitar mulut sarang untuk mengusir $T$. alba lain mendekati sarang. Pertarungan pasangan T. alba untuk pengusiran $T$. $a l b a$ lain ini di sertai dengan teriakan.

\section{KESIMPULAN}

1. Burung T. alba merupakan hewan nocturnal yang mengalokasikan waktu untuk aktivitas (bertengger, terbang, berburu dan memangsa, bercumbu dan bertarung) pada malam hari dan siang hari dihabiskan untuk beristirahat.

2. Burung T. alba betina aktivitas istirahat dan bertengger lebih tinggi dibandingkan $T$. alba jantan. T. alba betina cenderung proteksi terhadap sarang dari $T$. alba lain yang mendekati sarang.

3. T. alba jantan lebih banyak melakukan aktivitas terbang dan berburu dibanding burung $T$. alba betina, T. alba jantan bertanggung jawab dalam memenuhi nutrisi $T$. alba betina. 


\section{UCAPAN TERIMA KASIH}

Dalam pelaksanaan penelitian dan penulisan laporan ini tidak terlepas dari bantuan berbagai pihak. Maka tanpa bermaksud mengecilkan peran masing-masing pihak, penulis mengucapkan terima kasih yang sebesar-besarnya kepada :

saudara Dani Kristiyanto, Dwi Putranto, Hilman $\mathrm{N}$, yang telah banyak membantu penelitian ini. Dan semua pihak yang telah membantu dan tidak bisa disebutkan satu-persatu.

\section{DAFTAR PUSTAKA}

Anonim. 2002. Owling. http: //www.owli.com/ Bachynski, K. and M. Harris. 2002. Tyto alba" (On-line), Animal Diversity Web. http://animaldiversity. ummz. umich. edu/ site/ accounts/ informasi/ Tyto alba

Barn Owl Trust. 2001. Sexing Barn Owls. http://www.barnowltrust.org.uk.

Baskoro, K. 2005. Tyto alba : Biologi, Perilaku, Ekologi dan Konservasi. Pencinta Alam Haliaster Biologi. Universitas Diponegoro. Semarang.

del Hoyo, J., Elliott, A and Sargatal, J. 1999. Hand Book of the Brid of the World. Vol 5.barn owl to Hummingbird. Lynx Edicion. Barcelona.

Dinas pertanian tanaman pangan kab. Kendal. 1999. Pemanfaatan Burung Hantu Tyto alba Untuk Mengendalikan Hama Tikus Di Kabupaten Kendal. http://www.kabupaten-kendal. go. id.

Lewis, P.D.1998. The Owl Page. http://www. Owlpages.com.

Mackinnon, J., Philipps, K., Van Balen,B. 2000. Burung-burung di Sumatera, Jawa, Bali dan Kalimantan. Puslitbang Biologi LIPI.

Marlina, S. 2005. Pola Aktivitas Harian Rusa Totol (Axis axis Erxl) Dalam Penangkaran di Taman Monas Jakarta. Jurusan Biologi FMIPA UNDIP. Semarang. (Unphublicser)
Martin, JM. RN. Raid, and Lynn C. Branch. 2005. Barn Owl (Tyto alba). http://edis.ifas.ufl.edu

Nariswari, D dan P Yuda. 1997. Perilaku Berbiak Burung kuntul Kerbau (Bubulcus ibis) di Halaman Ambarukmo Palace, Yogyakarta. Biota, jurnal Ilmiah Fakultas Biologi Universitas Atma Jaya. Yogyakarta.

Prasetyo, DK. 2002. Studi Habitat Sekitar Sarang Elang Jawa (Spizaetus bartelsi) Di Kawasan Cibolau Taman Nasioanal Gede- Pangrango Jawa Barat. Jurusan Biologi FMIPA UNDIP. Semarang. (Unphublicser).

Read and Alsop. 1994. The Bran Owl. www.rw.ttu.edu/sp accounts/bran owl/ DEFAULT.htm

Setiawan. 2004. Tyto Alba Sahabat Petani. Lembaga Gita Pertiwi. Ngawi. Jawa Timur.

The Hawk and Owl Trust. 2004. The Barn Owl (Tyto alba). http//: www.hawkandowl.org 